\title{
Food Safety and Hygiene Practices among Street Food Vendors in Noida, Uttar Pradesh, India
}

\author{
Amit Kumar Singh, Narendra Pratap Singh and A.K. Chaturvedani* \\ Food and Drug Administration U.P., India \\ ICAR-Indian Veterinary Research Institute, Izatnagar, Bareilly, Uttar Pradesh-243 122, India \\ *Corresponding author
}

\begin{tabular}{l} 
Ke y w o r d s \\
$\begin{array}{l}\text { Safety, Hygiene, } \\
\text { Street food, Food } \\
\text { vendor }\end{array}$ \\
Article Info \\
$\begin{array}{l}\text { Accepted: } \\
16 \text { August } 2018 \\
\text { Available Online: } \\
\text { 10 September } 2018\end{array}$ \\
\hline
\end{tabular}

\section{Introduction}

The Food and Agricultural Organization (FAO) of the United Nations defines Street Foods as ready to eat food and beverages prepared and/or sold by vendors and hawkers especially in streets and other similar public place (1988). The trend of street food vending is mushrooming globally due to fast

\begin{abstract}
The present study was conducted on two hundred street food vendors randomly selected from New Okhla Industrial Development Authority (NOIDA) of Gautambudh Nagar district of Uttar Pradesh, to assess the food safety and hygienic practices among street food vendors. The information was collected with the help of questionnaire and observation of vending site. Data was entered and analyzed with the help of MS excel. The result revealed that Majority of the respondents $(42.5 \%)$ was in the age group of 15 to 30 years and $85 \%$ were male. Out of the total respondents, 35\% vendors have achieved primary level of education while $24 \%$ were illiterate. Around sixty percent of the vendors reported Rs. 10,000 and above as their monthly income. $45 \%$ of the respondents were not permanent residents of Uttar Pradesh. They have migrated from the other states of India like, Bihar, Madhya Pradesh and also West Bengal. Only 5\% vendors were registered. Majority of respondents $(88.0 \%)$ sell their food stuff on mobile cart. More than fifty per-cent vendors (62.5\%) prepared their foodstuffs at their own marketplace and half of the vendors prepared food at morning and during the sale. Majority of vendors (85\%) used the tap water for food preparation and $60 \%$ washed their utensils in cold water either in a bucket or directly from tap water. Over $61 \%$ did not give due preference to cover their food items and more than $80 \%$ of the stalls were exposed to flies. Majority of food vendors $(74 \%)$ did not use any serving fork or spoon while $98.0 \%$ served with bare hands. Most of the vendors $(98.0 \%)$ practiced to sell their food items without wearing gloves. $79.6 \%$ did not cover their head and $76.8 \%$ did not wear an apron. Less than a half of the food handlers washed their hands before food preparation and after using the toilet.

A B S T R A C T
\end{abstract}

urbanization, technological advancement and alarmingly increasing hasty lifestyle. People are more inclined to shop ready to eat foods instead of cooking at home. They are inclined towards easier ways of spending life without realizing about safety concerns. These foods provide a source of inexpensive, convenient and often nutritious food for both the urban and rural poor. It is estimated that 2.5 billion 
people worldwide consume street foods each day. Only in Latin America, street foods account for up to $30 \%$ of urban household purchases (Samapundo et al., 2015). In Southern Asian countries like India, Bangladesh, Bangkok, Thailand, and Indonesia, street foods are an important portion of their diet. Particularly for women in the developing world, street-vended foods also serve as a major source of livelihood providing a means of self-employment and the opportunity to develop business skills with low capital investment.

Despite the numerous benefits provided to people, street-vended foods can also be a source of food borne illnesses resulting from poor hygiene practices by vendors, insanitary conditions at food vending points, among others. According to Chapman et al., (2010) about $70 \%$ of disease outbreaks have been linked to street-vended foods while evidence provided by Mensah et al., (2002) point to the fact that, street foods are potential sources of enteropathogens.

Estimates by the World Health Organisation suggest that, food-borne illnesses account for about 2.2 million deaths annually, out of which about $86 \%$ are children.

Street food safety is highly dependent on the handling of raw food to the cooking of food till its consumption. The fact that street food vendors possess the underprivileged local infrastructure in general, lack of sanitary facilities, no proper training about food hygiene, poor sanitation and limited knowledge of personal hygiene have posed countless problems. Many studies conducted to assess the quality of street foods in various countries show that most of the times such food is not up to the safety standards, many are responsible for various food borne diseases and known to be the amongst greatest challenges of the $21^{\text {st }}$ century.
India is a rapid growing economy. Hence it also faces problem of rural - urban migration for employment opportunity. Due to this transition, food habits of people are getting affected. Nowadays, street food is becoming very popular and is in demand because it saves one's time and energy as eat. According to a study conducted by Sunita Mishra in Varanasi on safety aspect of street food it was found that about $82 \%$ of people of all age groups prefer to go to street vendors against $18 \%$ only who prefer to go to restaurants in the evening. $61 \%$ of the students in age group of 14- 21 years who consume foods from the street vendors at least once during the lunch break (Mishra, 2007). Vendors prepare food at home and sell or they prepare food at the site of selling. In India, varieties of ready to eat foods are available. This generally includes Chinese fast food, Paranthas, Puribhaji, Bhature and Kulche apart from lighter snacks like tea, biscuits, mathi, fan etc. This is the major source of income for the vendors and consumers get instant, tasty and cheap food in return. So Street Food Vending in urban areas especially in metropolitan cities has become an integral part of the urban lives and culture. It is also recognized that despite of good taste and easily availability, street food vendors are often poor, uneducated and lack hygiene practices. So street foods are perceived to be a major public health risk (WHO, 2013). According to WHO (1989), food handling personnel play important role in ensuring food safety throughout the chain of food production and storage. Mishandling and disregard of hygienic measures on the part of the street vendors may enable pathogenic bacteria to come into contact with and in some cases survive and multiply in sufficient numbers to cause illness in the consumer.

So this study tried to highlight the hygiene practices followed by vendors in Noida and also to gain insight on food safety and hygiene status of food they sell. 


\section{Materials and Methods}

Present study was conducted in Noida (New Okhala Industrial Development Authority) of Gautambudh Nagar district of Uttar Pradesh. Noida was selected purposely, on the basis of number of street food vendors. From Noida two hundred street food vendors operating in busy streets (Atta market sector 18, Bhangale), near colleges and offices were selected randomly. Data was collected through pretested questionnaire and results were presented in terms of frequency and percentage.

\section{Results and Discussion}

\section{Socio-economic characteristics of} respondents

Socio- Economic characteristics included the age, education, sex and income of the study subjects as presented in table 1. Majority of the respondents $(42.5 \%)$ was in the age group of 15 to 30 years. In the extreme age groups, i.e. below 15 years and above 45 years, less percentage of vendors were observed, only $2 \%$ and $20 \%$ respectively. Very few respondents were females $(15 \%)$ and majority of the vendors were male $(85 \%)$. Out of the total respondents, $35 \%$ of the vendors have achieved primary level of education while 24 $\%$ were illiterate. None of the vendors attained education more than intermediate level but $27.5,11 \%$ and $2.5 \%$ of the vendors have completed metric level, high school and intermediate level of education respectively. Around sixty percent of the vendors reported Rs. 10,000 and above as their monthly income. Next big percentage share in monthly income generation was $31 \%$ vendors, who were earning between Rs. 5000- 10000 in a month. Small chunk of total respondents (9\%) were able to earn between Rs. 1000- 5000 in a month. Around $45 \%$ of the respondents were not permanent residents of Uttar Pradesh.
They have migrated from the other states of India like, Bihar, Madhya Pradesh and also West Bengal. Few vendors have migrated from Nepal also. Chander Pal Thakur, et al., (2013) in Delhi reported the similar findings.

\section{Occupational traits of the respondents}

Basic occupational information of the vendors is shown in Table 2. Majority of street food vendors (95\%) were not registered under Food Safety and Standard Authority of India only 5\% vendors having Food Safety and Standard Authority of India (FSSAI) registration certificate. In $95 \%$ of the responses, vending operation was full time. Rests of the vendors were doing it part time. Majority of vended food was observed to be Biryani (veg, chicken, mutton), Chhola Bhatura, Kulcha, Momose (veg, paneer, chicken), Chowmeen, Paratha (aalu, paneer), Puri Subji, Rolls, Tikka (Paneer, chicken), Gol-gappe (Chaat), Fruit Juice, Sugarcane Juice.

As far as experience in vending is concerned majority of respondents (40\%) having 6-10 year experience followed by 11-15 year $(25 \%)$. Eighty eight per-cent of the vendors were selling their food stuff on mobile carts locally known as Thela followed by Dhabas (11\%) known as roadside mini restaurants while $3.0 \%$ had a wooden cart fixed near footpath. Zaheer et al., (2017) in Rawalpindi Pakistan reported the similar findings.

\section{Food handling and preparation practices}

In present study food handling and preparation practices were carefully observed, Table 2 reveals that majority of vendors $(62.5 \%)$ prepared their foodstuffs at their own marketplace followed by At home + own market place $(22.5 \%)$ and at home $(10.5 \%)$ while $4.5 \%$ vendors bring food stuff from other site. Around half of the vendors prepared food at morning and during the sale. 
Int.J.Curr.Microbiol.App.Sci (2018) 7(9): 2340-2347

Table.1 Socio-economic characteristics of street food vendors

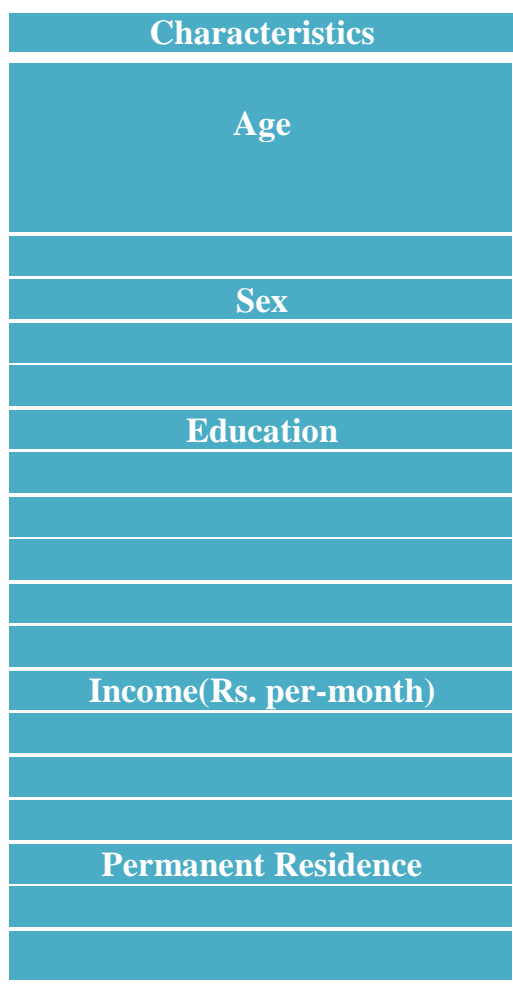

\begin{tabular}{|c|c|c|}
\hline Categories & Frequency (n) & Percentage (\%) \\
\hline Below 15 years & 04 & $2.0 \%$ \\
\hline $15-30$ years & 85 & $42.5 \%$ \\
\hline $30-45$ years & 70 & $35.0 \%$ \\
\hline Above 45 years & 41 & $20.5 \%$ \\
\hline Male & 170 & $85.0 \%$ \\
\hline Female & 30 & $15.0 \%$ \\
\hline Illiterate & 48 & $24.0 \%$ \\
\hline Primary & 70 & $35.0 \%$ \\
\hline Metric & 55 & $27.5 \%$ \\
\hline High School & 22 & $11.0 \%$ \\
\hline Intermediate & 05 & $2.5 \%$ \\
\hline $1000-5000$ & 19 & $9.5 \%$ \\
\hline $5000-10000$ & 62 & $31.0 \%$ \\
\hline $10000-20000$ & 52 & $26.0 \%$ \\
\hline $20000-30000$ & 40 & $20.0 \%$ \\
\hline $30000-50000$ & 20 & $10.0 \%$ \\
\hline Uttar Pradesh & 110 & $55.0 \%$ \\
\hline Bihar & 60 & $30.0 \%$ \\
\hline West Bengal & 12 & $6.0 \%$ \\
\hline Madhya Pradesh & 04 & $2.0 \%$ \\
\hline Nepal & 14 & $7.0 \%$ \\
\hline
\end{tabular}

Table.2 Basic occupational traits of the vendors

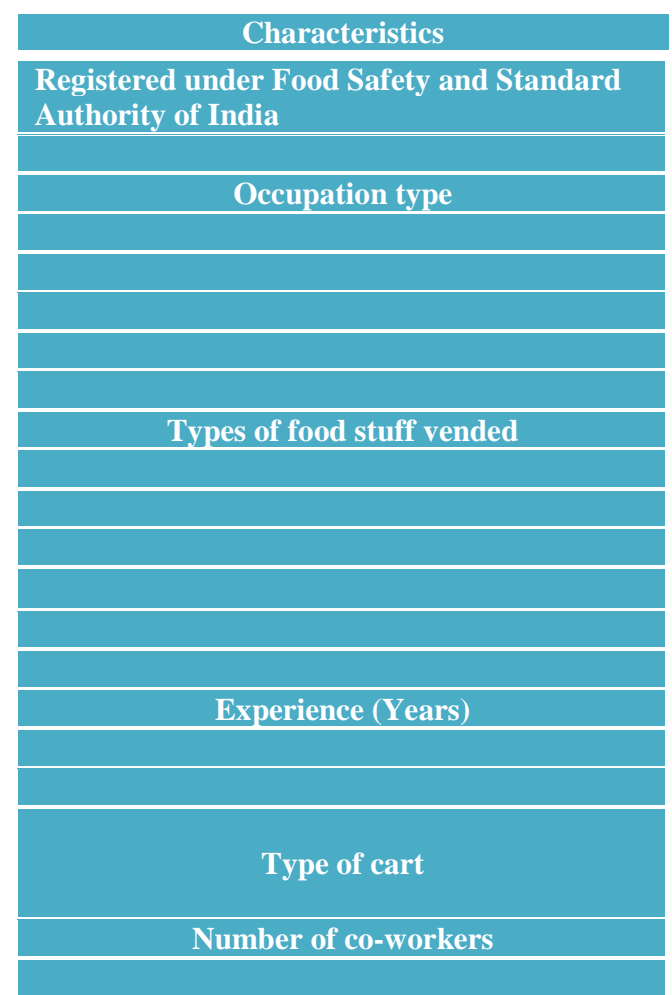

\begin{tabular}{|c|c|c|}
\hline Categories & Frequency $(\mathbf{n})$ & Percentage (\%) \\
\hline Yes & 190 & $95.0 \%$ \\
\hline No & 10 & $5.0 \%$ \\
\hline Full time & 190 & $95.0 \%$ \\
\hline Part time & 10 & $5.0 \%$ \\
\hline Biryani (Veg \& Non-Veg) & 52 & $26.0 \%$ \\
\hline Bhatura \& Kulcha & 40 & $20.0 \%$ \\
\hline Momose & 30 & $15.0 \%$ \\
\hline Chowmeen & 10 & $5.0 \%$ \\
\hline Paratha \& Puri Subji & 20 & $10.0 \%$ \\
\hline Rolls \& Tikka (Veg \& Non-Veg) & 16 & $8.0 \%$ \\
\hline Gol-gappe (Chaat) & 27 & $13.5 \%$ \\
\hline Fruit Juice & 15 & $7.5 \%$ \\
\hline Sugarcane Juice & 10 & $5.0 \%$ \\
\hline $1-5$ & 45 & $22.5 \%$ \\
\hline $6-10$ & 80 & $40.0 \%$ \\
\hline $11-15$ & 50 & $25.0 \%$ \\
\hline $16-20$ & 15 & $7.5 \%$ \\
\hline$>20$ & 10 & $5.0 \%$ \\
\hline Mobile carts & 172 & $88.0 \%$ \\
\hline Fixed cart & 6 & $3.0 \%$ \\
\hline Dhaba & 22 & $11.0 \%$ \\
\hline $1-3$ & 110 & $55.0 \%$ \\
\hline$>3$ & 90 & $45.0 \%$ \\
\hline
\end{tabular}


Table.3 Food handling, preparation and water consumption practices

\begin{tabular}{|c|c|c|c|}
\hline Variables & Categories & Frequency (n) & Percentage $(\%)$ \\
\hline & At home & 21 & $10.5 \%$ \\
\hline & At own market place & 125 & $62.5 \%$ \\
\hline \multirow[t]{4}{*}{ Preparation site } & At home + own market place & 45 & $22.5 \%$ \\
\hline & Get from another source & 9 & $04.5 \%$ \\
\hline & In the morning & 29 & $14.5 \%$ \\
\hline & During the sale & 68 & $34.0 \%$ \\
\hline \multirow[t]{3}{*}{$\begin{array}{c}\text { Timing of food } \\
\text { preparation }\end{array}$} & Morning + During the sale & 31 & $15.5 \%$ \\
\hline & At previous night + morning & 72 & $36.0 \%$ \\
\hline & Yes & 95 & $47.5 \%$ \\
\hline \multirow[t]{4}{*}{$\begin{array}{l}\text { Heating of food before } \\
\text { selling }\end{array}$} & No & 7 & $3.5 \%$ \\
\hline & Not required & 98 & $49.0 \%$ \\
\hline & Cold water & 30 & $15.0 \%$ \\
\hline & Warm water & 21 & $10.5 \%$ \\
\hline \multirow[t]{4}{*}{ Washing of utensil } & Detergents & 45 & $22.5 \%$ \\
\hline & Drying with cloth & 2 & $1.0 \%$ \\
\hline & Washing in bucket & 91 & $45.5 \%$ \\
\hline & Warm water+ Detergents+ Drying with cloth & 11 & $5.5 \%$ \\
\hline \multirow[t]{2}{*}{$\begin{array}{l}\text { Source of water for } \\
\text { preparation of food }\end{array}$} & Tap water & 170 & $85.0 \%$ \\
\hline & Filter water & 30 & $15.0 \%$ \\
\hline \multirow[t]{2}{*}{ Proper covering of food } & No & 121 & $60.5 \%$ \\
\hline & Yes & 79 & $39.5 \%$ \\
\hline \multirow[t]{2}{*}{ Presence of flies on food } & No & 24 & $12.0 \%$ \\
\hline & Yes & 176 & $88.0 \%$ \\
\hline \multirow[t]{2}{*}{$\begin{array}{c}\begin{array}{c}\text { Washing of food items } \\
\text { before use }\end{array} \\
\end{array}$} & No & 76 & $38.0 \%$ \\
\hline & Yes & 124 & $62.0 \%$ \\
\hline
\end{tabular}

Table.4 Serving of food

\begin{tabular}{|r|c|c|c|}
\hline Variables & Categories & Frequency (n) & Percentage (\%) \\
\hline $\begin{array}{r}\text { Serving with fork } \\
\text { and spoon }\end{array}$ & No & 148 & $74.0 \%$ \\
\hline & Yes & 52 & $26.0 \%$ \\
\hline $\begin{array}{r}\text { Food served with } \\
\text { bare hands }\end{array}$ & No & 4 & $2.0 \%$ \\
\hline & Yes & 196 & $98.0 \%$ \\
\hline & Paper bag & 15 & $7.5 \%$ \\
\hline & Polythene bag & 18 & $9.0 \%$ \\
\hline $\begin{array}{r}\text { Type of utensils used } \\
\text { for serving food }\end{array}$ & Stainless steel & 30 & $15.0 \%$ \\
\hline & Plastic & 12 & $6.0 \%$ \\
\hline & Disposable & 125 & $62.5 \%$ \\
\hline
\end{tabular}


Table.5 Personal hygienic profile of the food handlers

\begin{tabular}{|c|c|c|c|}
\hline Personal hygiene & Categories & Frequency (n) & Percentage (\%) \\
\hline \multirow[t]{2}{*}{ Use of gloves } & No & 192 & $98.0 \%$ \\
\hline & Yes & 8 & $4.0 \%$ \\
\hline \multirow[t]{2}{*}{ Use of head covering } & No & 179 & $89.5 \%$ \\
\hline & Yes & 21 & $10.5 \%$ \\
\hline \multirow[t]{3}{*}{ Use of apron } & No & 146 & $73.0 \%$ \\
\hline & Yes & 44 & $22.0 \%$ \\
\hline & Daily & 0.0 & $0.0 \%$ \\
\hline \multirow[t]{5}{*}{ Washing of all coverings } & After one day & 4 & $2.0 \%$ \\
\hline & After two day & 41 & $20.5 \%$ \\
\hline & Weekly & 155 & $77.5 \%$ \\
\hline & $\begin{array}{l}\text { Before } \\
\text { preparation of } \\
\text { food }\end{array}$ & 73 & $36.5 \%$ \\
\hline & $\begin{array}{l}\text { After touching } \\
\text { each food } \\
\text { Items }\end{array}$ & 20 & $10.0 \%$ \\
\hline \multirow[t]{2}{*}{ Hand washing } & $\begin{array}{l}\text { After using } \\
\text { toilet }\end{array}$ & 23 & $11.5 \%$ \\
\hline & $\begin{array}{c}\text { Before } \\
\text { preparation of } \\
\text { food + After } \\
\text { using toilet }\end{array}$ & 84 & $42.0 \%$ \\
\hline
\end{tabular}

Nevertheless, there were two exceptions fruit Chaat $(76.7 \%)$ and the sugar cane juice $(100 \%)$ are the items which were freshly sold by the vendors; seem to be the good practice among the vendors. seem to be the good practice among the vendors. Furthermore results regarding handling practices among vendors from different clusters showed that over $61 \%$ did not give due preference to cover their food items and the remaining practiced to cover their food but it was not properly covered therefore more than $80 \%$ of the stalls were exposed to flies. Chander Pal Thakur et al., (2013) in Delhi reported the similar findings.

Majority of vendors (85\%) used the tap water for food preparation supplied by Noida Industrial Development Authority. Only fifteen per-cent vendors used filtered/ R.O water. Out of $200,60 \%$ washed their utensils in cold water either in a bucket or directly from tap water, significantly seen in vendors with mobile carts and stalls near to footpath. The severity of contamination seemed to multiply when same water was reused for multiple times, especially on mobile carts having buckets for cleaning purpose. Similar findings were reported by Zaheer et al., (2017) in Rawalpindi Pakistan.

\section{Serving of food}

Food serving practices by the vendors are revealed in Table 3. Majority of food vendors (74\%) did not use any serving fork or spoon while $98.0 \%$ served with bare hands. Since bare hands cause food contamination as 
enteropathogens can survive on hands for three hours or longer. The serving utensils are equally important. It was found that more than sixty per-cent $(62.5 \%)$ used to sell their food in disposable utensils - mainly, the Chaat, Chowmeen, Momos. Stainless metallic utensils were used to serve Chhole Bhature, Chhole Kulche, Poori Subji rice and juices by fifteen per-cent vendors. Chander Pal Thakur, et al., (2013) in Delhi reported the similar findings.

In the present study, it was observed that 7.5 $\%$ vendors sold food also in paper bags, plain and with old and fresh newsprints. Since, these bags use gums / glues that are not recommended by any food control authority, plus papers are scavenged from unknown sources, we believe that the origin of these bags in itself is questionable. About 9\% vendors used the polythene bags.

\section{Personal hygiene of food handlers}

Personal hygienic practices of food handlers rank amongst the major concerns that may potentially lead towards foodborne outbreaks. In this study, personal hygiene was assessed in terms of usage of gloves, head coverings, apron and hand washing of the respondents. The study revealed that most of the vendors (98.0\%) practiced to sell their food items without wearing gloves. $79.6 \%$ did not cover their head and $76.8 \%$ did not wear an apron. Less than a half of the food handlers washed their hands before food preparation and after using the toilet. Chander Pal Thakur et al., (2013) in Delhi reported the similar findings.

The study concluded that vendors are not selling the safe food to consumers. Their main objective is money making without considering the health of community. Positive aspect of the study was that, vendors were willing to have food safety training and learn about the key traits of food safety. So there is an immense need to impose education on the food safety knowledge and practices before vendors are allowed to trade. Street food stalls should be registered and the sanitary condition of street food production should be monitored. Most of the vendors possessed good knowledge of health and personal hygiene. They still need to put their knowledge into practice. For making sure of that, authority supported awareness raising training programs and periodic monitoring should be introduced to street food vending in Noida.

\section{References}

Afele, M. (2006). Strefet food boom in Ghana spurs calls for better hygiene. Bulletin of the World Health Organization. 84(10): 765-840.

Ahmed, Z., Afreen, A., Hassan, M.U., Ahmad, H., Anjum, N. and Waseem, M. (2017). Exposure of Food Safety Knowledge and Inadequate Practices among Food Vendors at Rawalpindi; the Fourth Largest City of Pakistan, Journal of Food and Nutrition Research, 5 (1):63-73.

Aluko, O. O., Ojeremi, T. T., Olaleke, D. A. and Ajidagba, E. B. (2014). Evaluation of food safety and sanitary practices among food vendors at car parks in Ile Ife, southwestern Nigeria, Food Control, 40, 165-171

Amponsah-Doku, F., Obiri-Danso, K., Abaidoo, R., Drechsel, P. and Kondrasen, F. (2010). Bacterial contamination of lettuce and associated risk factors at production sites, markets and street food restaurants in urban and peri-urban Kumasi, Ghana, Scientific Research and Essays, 5, 217-223.

Atter, A., Ofori, H., Anyebuno, G. A., AmooGyasi, M. and Amoa-Awua, W. K. (2015). Safety of a street vended traditional maize beverage, ice-kenkey, in Ghana, Food Control, 55, 200-205.

Chapman B, Eversley T, Fillion K, Maclaurin T, Powell D. (2010). Assessment of food safety practices of food service food handlers (risk assessment data): testing a 
communication intervention (evaluation of tools). J Food Prot. 73(6):1101-7.

Da Silva, S. A., Cardoso, R. d. C. V., Góes, J. Â. W., Santos, J. N., Ramos, F. P., De Jesus, R. B. et al., (2014). Street food on the coast of Salvador, Bahia, Brazil: A study from the socioeconomic and food safety perspectives, Food Control, 40, 78-84.

Essential safety requirements for street-vended foods (revised edition). Food safety unit, Division of food and nutrition, World Health Organization. (http://www.who.int/ foodsafety/publications/fs_management/en/ streetvend.pdf, accessed on 8th October, 2013).

Food and Agricultural Organization. Street Foods. Report of an FAO expert consultation, Indonesia, 5 - 9 December 1988.

Health surveillance and management procedures for food handling personnel, WHO technical report series, 785, WHO, Geneva, 1989.

Lin, W.I. and Yamao, M. (2014). Street foods safety in Yangon: A case study on street food vendoro socio-economics and production aspects. Proceedings of the First Asia-Pacific Conference on Global Business, Economics, Finance and Social Sciences (AP14Singapore Conference).

Lues, J.F.R., Rasephei, M.R., Venter, P., Theron, M.M. (2006). Assessing food safety and associated food handling practices in street food vending. Int. J. Environ. Health Res., 16, 319-328.

Mensah, P., Yeboah-Manu, D., Owusu-Darko, K. and Ablordey, A. (2002). Street foods in Accra, Ghana: how safe are they? Bulletin of the World Health Organization, 80 (7): 546-554.
Mishra, S. (2007). Safety aspects of street foods: A case study of city of Varanasi. Indian Journal of Preventive Social Medicine, volume 38 No. $1 \& 2$.

Monney, I., Agyei, D., Ewoenam, B.S., 1, Priscilla, C. and Nyaw, S., (2014). Food hygiene and Safety Practices among Street Food Vendors: An Assessment of Compliance, Institutional and Legislative Framework in Ghana. Food and Public Health, 4(6): 306-315.

Proietti, I., Frazzoli, C. and Mantovani, A. (2014). Identification and management of toxicological hazards of street foods in developing countries, Food and chemical toxicology, vol. 63, pp. 143-152.

Samapundo, S., Climat, R., Xhaferi, R. and Devlieghere, F. (2015). Food safety knowledge, attitudes and practices of street food vendors and consumers in Port-auPrince, Haiti, Food Control, vol. 50, pp. 457-466.

Saravanan, A.V., Sibyl, S., Bennadi, D. and Kshetrimayum, N., (2016). Food Safety among Food Vendors in Chennai City-A Cross Sectional Surve. Int J Pharma Res Health Sci.; 4 (6):1466-1469.

Thakur, C.P., Mehra, R., Narula, C., Mahapatra, S. and Kalita, T.J. (2013). Food Safety and Hygiene Practices Among Street Food Vendors in Delhi, India. International Journal of Current Research, 5(11): 35313534.

WHO (2008). Essential Safety Requirements for Street Vended Foods. Available online:http://www.who.int/foodsafety/publi ctions/fs_management/en/streetvend.pdf.

\section{How to cite this article:}

Amit Kumar Singh, Narendra Pratap Singh and Chaturvedani, A.K. 2018. Food Safety and Hygiene Practices Among Street Food Vendors in Noida, Uttar Pradesh, India. Int.J.Curr.Microbiol.App.Sci. 7(09): 2340-2347. doi: https://doi.org/10.20546/ijcmas.2018.709.291 